\title{
Pengendalian Kualitas Proses Pengemasan Gula Karung Menggunakan Metode Statistical Process Control (SPC)
}

\author{
Rizaldi Sardani ${ }^{1}$, Devi Faradil ${ }^{1}$, Suci Oktri Viarani $M^{1}$, Eko Supriadi ${ }^{2}$ \\ ${ }^{I}$ Program Studi Manajemen Logistik Industri Agro, Politeknik ATI Padang,Bungo Pasang-Tabing, Padang 25171 Indonesia \\ ${ }^{2}$ Program Studi Teknik Kimia Bahan Nabati, Politeknik ATI Padang, Bungo Pasang-Tabing, Padang 25171 Indonesia
}

\section{ARTICLE INFORMATION}

Received: June 12, 2019

Revised: June 20, 2019

Accepted: June 27, 2020

\section{KEYWORD}

Quality,

Packaging,

Seven Tools,

Statistical Process Control

\section{CORRESPONDENCE}

Name: Rizaldi Sardani

E-mail: rizaldi.sardani@poltekatipdg.ac.id

\section{A B S T R A C T}

Quality is a benchmark to determine the level of good and bad of a product. The level of quality of a product will affect customer satisfaction, hence, to produce high quality products, it is necessary for a company to have a quality control process. Quality control is a process that aims to maintain the quality of products and services that have been promised to consumers. In this study, quality control is carried out in the sugar packaging process. Where in the sugar packaging process found the resulting product has a poor quality, defective and not in accordance with specifications. This study uses the Statistical Process Control (SPC) method which aims to determine the causes of defective products with the intention that the packaging process can further minimize the level of product defects. The SPC method is a statistical analysis technique with seven statistical tools or seven tools. Based on the results of the study it can be seen that the cause of product damage / defects in the product packaging process is caused by three types of damage namely damage due to conveyor $(38.17 \%)$, damage due to machine pinched $(35.82 \%)$, and damage due to loose seams $(26,00 \%)$ This type of damage can be caused by human error and other factors such as engine condition, engine cleanliness and the monitoring process. Proposed improvements recommended for the company are to provide training to employees, make clear work instructions, conduct periodic maintenance for the machines used, supervise all work areas, and carry out quality control for every acceptance of raw materials.

\section{PENDAHULUAN}

Setiap perusahaan wajib memperhatikan kualitas produk yang dihasilkannya. Kualitas produk yang terjaga akan membawa dampak baik bagi perusahaan baik secara langsung ataupun tidak langsung. Produk yang memiliki kualitas yang baik lebih disukai konsumen. Hal ini tentu saja membawa keuntungan bagi perusahaan. Di sisi lain jika produk yang dihasilkan sudah memenuhi standar kualitas, perusahaan tidak perlu melaksanakan pekerjaan ulang yang memakan waktu dan biaya.

Memahami dan meningkatkan kualitas merupakan faktor utama dalam kesuksesan, pertumbuhan dan peningkatan daya saing perusahaan [1]. Sejalan dengan itu, perusahaan yang memiliki produk berkualitas tinggi menikmati keuntungan yang signifikan atas pesaingnya [2]. Maka dari itu, pemahaman atas pengendalian kualitas produk merupakan hal yang penting bagi perusahaan.
Setiap perusahaan memiliki bagian atau departemen yang masing-masingnya memiliki peran yang saling berkaitan untuk mencapai tujuan perusahaan. Biasanya untuk proses pengujian bahan baku dan produk jadi baik itu dalam bentuk fisik maupun non fisik dikerjakan oleh bagian Quality Control yang betugas memastikan bahan baku dan produk jadi sudah memenuhi standar yang telah ditetapkan [3].

Metode Statistical Process Control (SPC) merupakan metode pengendalian kualitas dengan menggunakan Tujuh Alat Bantu (Seven Tools). Tujuan dari metode ini adalah untuk mengantisipasi terjadinya kesalahan atau cacat dengan menggunakan langkah-langkah terukur dan terstruktur, berdasarkan data yang ada [1].

Salah satu proses yang mempengaruhi kualitas produk adalah pengemasan. Suatu produk dapat mengalami penurunan kualitas selama proses produksi. Suatu bahan dapat terkontaminsai selama proses manufaktur dan pengemasan [4]. Kemasan yang tidak baik akan membawa kerugian bagi perusahaan. Kemasan yang 
tidak sesuai standar mengakibatkan kerugian waktu produksi, kerugian bahan, munculnya keluhan dan ketidakpuasan pelanggan [5].

Salah satu industri yang memiliki pengemasan adalah industri gula PT. Q yang berlokasi di Jawa Timur. PT Q merupakan sebuah industri yang memproduksi gula kristal. Berdasarkan pengamatan yang sudah dilakukan pada proses pengemasan terdapat permasalahan mengenai pengandalian kualitas. Proses pengemasan tersebut bertujuan untuk melanjutkan hasil kerja dari stasiun putaran berupa gula basah yang sudah diproses menjadi gula kering untuk kemudian dikemas. Stasiun putaran menghasilkan produk yang disebut dengan gula produksi. Gula produksi ini kemudian dibawa oleh talang goyang menuju ke alat pengeringan gula. Gula kering yang keluar dari alat pengeringan diangkut dengan bucket elevator menuju ayakan getar. Ayakan getar terbagi menjadi dua tingkat, yang pertama memisahkan gula krikilan, gula standar. Gula krikilan dilebur untuk bibitan masakan, sedangkan gula standar dikemas dalam karung $50 \mathrm{~kg}$ kemudian dijahit, selanjutnya dimasukkan ke gudang dengan belt conveyor.

Dimana berdasarkan pengamatan pada periode Mei 2017 - November 2018 ditemukan kerusakan kemasan gula. Berdasarkan fenomena tersebut, penelitian ini mengamati dan mengkaji pengendalian kualitas pada proses pengemasan gula. Dimana pada proses pengemasan gula ditemukan produk yang dihasilkan memiliki kualitas yang kurang baik, cacat dan tidak sesuai dengan spesifikasi yang ditetapkan. Tujuannya untuk mengetahui faktor penyebab terjadinya kerusakan pada pengemasan gula dengan menggunakan metode SPC serta memberikan usulan/rekomendasi perbaikan bagi perusahaan utnuk dapat menghasilkan produk yang sesuai standar.

\section{METODOLOGI}

\section{Sumber dan Jenis Data}

Berikut adalah sumber data yang diperoleh:

1. Data Primer

Data primer dalam penelitian ini adalah data tenanting produk cacat dalam proses pengemasan gula yang didapat secara langsung.

2. Data Sekunder

Dalam penelitian ini data yang dibutuhkan adalah data produk gula yang cacat pada proses pengemasan.

Jenis data yang digunakan pada penelitian ini adalah jenis data kuantitatif yang merupakan data yang dapat dihitung.

\section{Teknik Pengumpulan Data}

Teknik pengumpulan data dilakukan dengan cara observasi langsung, wawancara dan studi pustaka.

1. Wawancara

Wawancara yang dilakukan berupa tanya jawab secara langsung dengan karyawan bagian pengemasan mengenai proses pengemasan gula dengan karung.

2. Observasi

Observasi dilakukan berupa pengamatan secara langsung terhadap permasalahan yang akan diteliti, serta memeriksa data dan fakta di lapangan tentang proses pengemasan.

3. Studi Pustaka

Proses pengumpulan data dengan cara mempelajari literatur yang terkait penelitian, berupa buku dan jurnal yang berkaitan dengan pengendalian kualitas proses pengemasan produk.

\section{Metode Penelitian}

Metode penelitian yang digunakan dalam penelitian ini adalah metode Statistical Process Control (SPC). Pada penelitian ini, alat bantu yang digunakan hanya beberapa teknik analisis yaitu Check Sheet, Histogram, Peta Kendali, Diagram Pareto, dan Diagram Sebab Akibat (fishbone).

Langkah-langkah analisis data yang dilakukan adalah

1. Check Sheet

Lembar Check Sheet itu diperoleh dari data produksi dan data produk cacat dari perusahaan yang kemudian diolah menjadi tabel yang terukur. Tujuannya untuk memudahkan dalam memahami data.

2. Histogram

Data Check Sheet yang sudah diubah menjadi tabel kemudian disajikan dalam bentuk Histogram yang berupa alat penyajian data secara visual dalam bentuk grafik balok.

3. Diagram Pareto

Setelah data disajikan dalam histogram, selanjutnya data disajikan dalam bentuk diagram pareto yang memperlihatkan data dalam bentuk grafis untuk mengetahui persentase jenis produk cacat tertinggi.

4. Peta Kendali

Mengidentifikasi setiap kondisi yang tidak terkendali secara statistik dengan control chart. Rumus yang digunakan dalam control chart atau peta kendali pada penelitian ini yaitu peta kendali $\mathrm{P}$.

Adapun langkah-langkah dalam membuat peta kendali p adalah sebagai berikut [6]:

a. Mencatat dan mengumpulkan data untuk setiap sub grup/periode tentang jumlah yang diperiksa dan jumlah yang cacat. 
b. Menghitung proporsi kerusakan p untuk setiap sub grup/periode, dengan rumus :

$p=\frac{\text { Jumlah Cacat }}{\text { Ukuran Jumlah Sub Grup }}=\frac{n p}{n}$

Keterangan:

$\mathrm{p}=$ Proporsi Kerusakan

$\mathrm{np}=$ Jumlah cacat dalam sub grup/periode

$\mathrm{n}=$ Jumlah yang diperiksa dalam sub grup/periode

c. Menghitung Garis Pusat / Central Line (CL)

$C L=\frac{\text { Jumlah Total yang cacat }}{\text { Jumlah Total yang diperiksa }}=\frac{\sum n p}{\sum n}$

Keterangan:

$\sum n p=$ Jumlah total yang cacat

$\sum n=$ Jumlah total yang diperiksa

d. Menghitung batas kendali atas atau Upper Control Limit (UCL)

$U C L=C L+3 \sqrt{\frac{C L(1-C L)}{n}}$

Keterangan:

$\mathrm{n}=$ Jumlah produksi dalam sub grup/periode

e. Menghitung batas kendali bawah atau Lower Control Limit (LCL)

$U C L=C L-3 \sqrt{\frac{C L(1-C L)}{n}}$ f. Membuat Peta Kendali

g. Jika terdapat titik berada di luar batas UCL dan LCL artinya produk cacat yang dihasilkan periode tersebut berada di atas atau dibawah toleransi yang ditetapkan.

5. Diagram Sebab Akibat

Mencari faktor penyebab yang dominan dengan menggunakan diagram sebab akibat (cause and effect diagram).

6. Membuat usulan perbaikan berdasarkan data Sebab Akibat terjadinya kerusakan produk.

\section{HASIL DAN PEMBAHASAN}

\section{Check Sheet}

Berdasarkan dari hasil pengumpulan data yang telah dilakukan dapat diklasifikasikan jenis-jenis cacat yang terjadi selama proses pengemasan produk gula karung yaitu; cacat karena terjepit mesin, cacat karena jahitan lepas dan cacat karena conveyor. Dari hasil tersebut kemuadian dianalisis faktor penyebab terjadinya produk cacat menggunakan alat bantu statistik bantu statistik seven tools. (lembar pengecekan atau check sheet, histogram, diagram pareto, peta kendali $\mathrm{p}$, dan diagram sebab akibat).

Adapun hasil pengamatan data melalui check sheet sudah dirangkum ke dalam bentuk tabel seperti pada Tabel 1.

Tabel 1. Data Jumlah Produksi dan Produk Cacat

\begin{tabular}{|c|c|c|c|c|c|}
\hline \multirow{2}{*}{ Bulan } & \multirow{2}{*}{$\begin{array}{l}\text { Total Produksi } \\
\quad \text { (karung) }\end{array}$} & \multicolumn{3}{|c|}{ Cacat (karung) } & \multirow{2}{*}{$\begin{array}{c}\text { Jumlah Caca } \\
\text { (karung) }\end{array}$} \\
\hline & & Cacat Conveyor & Jahitan Lepas & Terjepit Mesin & \\
\hline Mei 2017 & 387999 & 86 & 60 & 188 & 334 \\
\hline Juni 2017 & 388196 & 140 & 58 & 116 & 314 \\
\hline Juli 2017 & 365981 & 78 & 76 & 65 & 219 \\
\hline Agustus 2017 & 396911 & 103 & 73 & 83 & 259 \\
\hline September 2017 & 406034 & 130 & 68 & 70 & 268 \\
\hline Oktober 2017 & 379878 & 84 & 180 & 76 & 340 \\
\hline November 2017 & 388661 & 147 & 80 & 94 & 321 \\
\hline Mei 2018 & 411130 & 96 & 63 & 97 & 256 \\
\hline Juni 2018 & 416323 & 150 & 58 & 127 & 335 \\
\hline Juli 2018 & 415316 & 87 & 107 & 158 & 352 \\
\hline Agustus 2018 & 429065 & 161 & 54 & 69 & 284 \\
\hline September 2017 & 424193 & 84 & 73 & 163 & 320 \\
\hline Oktober 2018 & 415706 & 271 & 48 & 187 & 506 \\
\hline November 2017 & 428167 & 58 & 143 & 79 & 280 \\
\hline Total & 5653560 & 1675 & 1141 & 1572 & 4388 \\
\hline
\end{tabular}


Berdasarkan Tabel 1. dapat dilihat bahwa sub grup/periode yang diperiksa dari bulan Mei 2017 sampai November 2017 dan bulan Mei 2018 sampai November 2018 dimana jumlah total produk yang diperiksa adalah 5653560 karung sedangkan total produk cacatnya sebesar 4388 karung.

\section{Histogram}

Data Check Sheet yang sudah diubah menjadi tabel kemudian disajikan dalam bentuk Histogram yang berupa alat penyajian data secara visual dalam bentuk grafik balok.

Histogram dari hasil pengolahan data Tabel 1. Dapat dilihat pada Gambar 1. Dari Gambar 1. dapat dilihat bahwa jumlah produk cacat yang terbanya adalah pada bulan Oktober 2018 sebesar 506 karung. Untuk melihat sebaran jenis cacat setiap bulan dapat dilihat pada Gambar 2.
Pada Gambar 2. Dapat dilihat jenis cacat terjepit mesin yang terbesar yaitu pada bulan Oktober 2018 sebesar 271 karung, untuk jenis cacat jahitan lepas terbesar yaitu pada bulan Oktober 2017 sebesar 180 karung dan untuk jenis cacat conveyor terbesar yaitu pada bulan Mei 2017 dan Oktober 2018 masing-masingnya sebesar 188 karung dan 187 karung.

\section{Diagram Pareto}

Diagram pareto (pareto chart) merupakan diagram yang digunakan untuk mengidentifikasi, mengurutkan, dan bekerja untuk menyisihkan pada produk cacat atau not good secara permanen. Dengan diagram ini, maka dapat diketahui jenis cacat yang paling dominan. Diagram Pareto dari hasil pengolahan data dapat dilihat pada Gambar 3.

Berdasarkan Gambar 3. dapat dilihat bahwa faktor terbesar penyebab kerusakan terjadi karena cacat conveyor, faktor kedua karena terjepit mesin dan penyebab terakhir karena jahitan lepas.

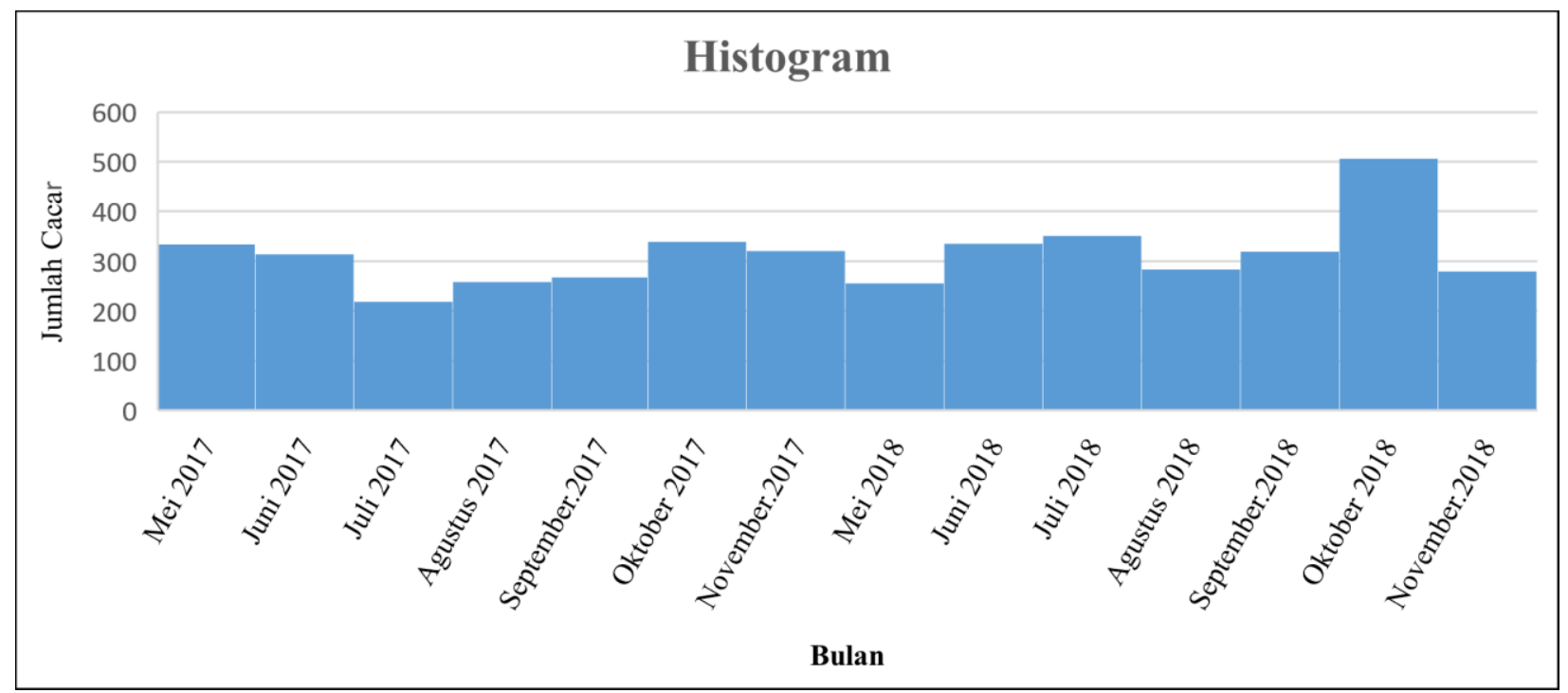

Gambar 1. Histogram Cacat Keseluruhan 


\section{Histogram}

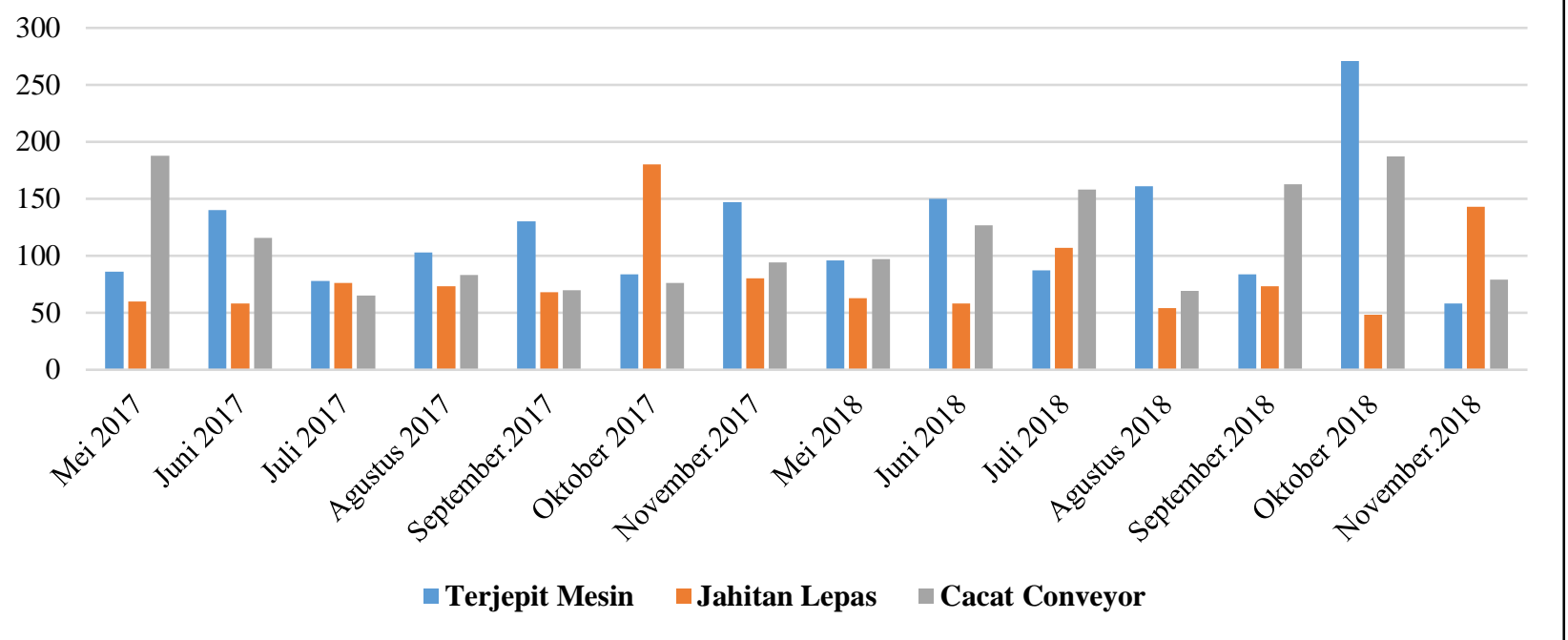

Gambar 2. Histogram Cacat Produk Berdasarkan Jenis

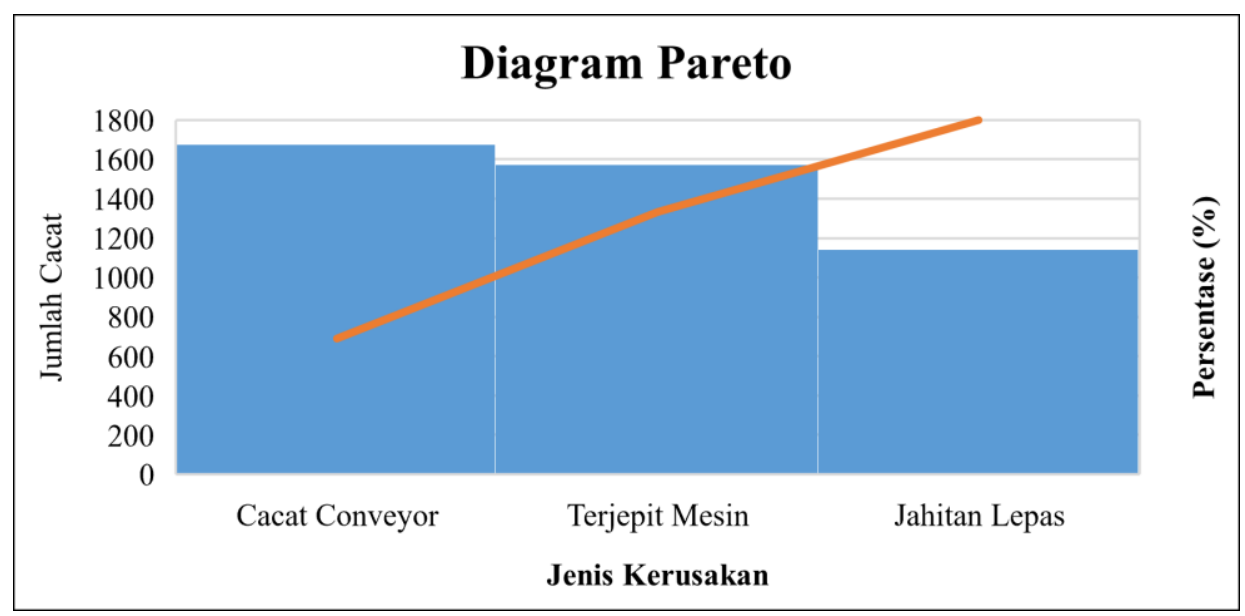

Gambar 3. Diagram Pareto

\section{Peta Kendali}

1. Mencatat dan mengumpulkan data untuk setiap sub grup/periode tentang jumlah yang diperiksa dan jumlah yang cacat.

2. Menghitung proporsi kerusakan $\mathrm{p}$ untuk setiap sub grup/periode, dengan rumus (1):
a. sub grup/periode 1 :
$p=\frac{n p}{n}=\frac{334}{387999}=$ 0,00086
b. sub grup/periode 2 : 0,00081
c. dan seterusnya

Dari hasil perhitungan proposi setiap sub grup/periode diperoleh proposi kecacatan pada subgroup 1 sebesar 0,00086 artinya tingkat cacat yang dihasilkan $0,086 \%$ dari kesuluruhan total produksi.

3. Menghitung Garis Pusat/ Central Line (CL)
Menghitung nilai CL dengan menggunakan rumus (2):

$C L=\frac{\sum n p}{\sum n}=\frac{4388}{5653560}=0,000776$

Dari hasil perhitungan garis pusat/central line diperoleh nilai sebesar 0,000776 artinya rata-rata tingkat kecacatan

yang terjadi pada periode Mei 2017 sampai November 2017 dan Mei 2018 sampai November

2018 adalah 0,0776 \% dari keseluruhan total produksi.

4. Menghitung batas kendali atas atau Upper Control Limit (UCL)

Menghitung nilai UCL dengan menggunakan rumus (3):

a. sub grup/periode 1 : 


$$
U C L=0,00076+3 \sqrt{\frac{0,00076(1-0,00076)}{387999}}=
$$$$
0,00077636
$$

b. sub grup/periode 2 :

$U C L=0,00076+3 \sqrt{\frac{0,00076(1-0,00076)}{388196}}=$ 0,00077636

c. dan seterusnya

Dari hasil perhitungan batas kendali atas setiap sub grup/periode diperoleh nilai untuk sub grup/periode 1 sebesar 0,00077636 dan untuk sub grup/periode 2 sebesar 0,00077636. Artinya jika produk cacat yang dihasilkan berada di atas nilai batas kendali atas (maksimum) maka perlu adanya tindakan perbaikan untuk proses yang dilakukan.

5. Menghitung batas kendali bawah atau Lower Control Limit (LCL)

Menghitung nilai LCL dengan menggunakan rumus (4):

a. sub grup/periode 1 :

$$
\begin{aligned}
& L C L=0,00076-3 \sqrt{\frac{0,00076(1-0,00076)}{387999}}= \\
& 0,00077593
\end{aligned}
$$

b. sub grup/periode 2 :

$$
\begin{aligned}
& L C L=0,00076-3 \sqrt{\frac{0,00076(1-0,00076)}{388196}}= \\
& 0,00077593
\end{aligned}
$$

c. dan seterusnya

Dari hasil perhitungan batas kendali bawah setiap sub grup/periode diperoleh nilai untuk sub grup/periode 1 sebesar 0,00077593 dan untuk sub grup/periode 2 sebesar 0,00077593. Artinya jika produk cacat yang dihasilkan berada di bawah nilai batas kendali bawah (minimum) maka perlu adanya tindakan mempertahankan kinerja pada periode tersebut karena jumlah produk cacat yang dihasilkan berada di bawah rara-rata tingkat cacat yang ditentukan.

6. Membuat Peta Kendali

Peta kendali dibuat berdasarkan nilai dari UCL, CL, LCL dan di nilai $\mathrm{p}$ (nilai produk cacat pada setiap periode), Berdasarkan perhitungan UCL, CL dan LCL yang sudah dilakukan diperoleh nilai yang hampir sama atau bisa dikatakan batas kendali atas dan bawah memiliki rentang nilai yang sangat kecil. Sehingga pada Peta kendali $p$ yang dapat dilihat pada Gambar 4. terlihat grafik UCL, CL dan LCL berhimpitan .

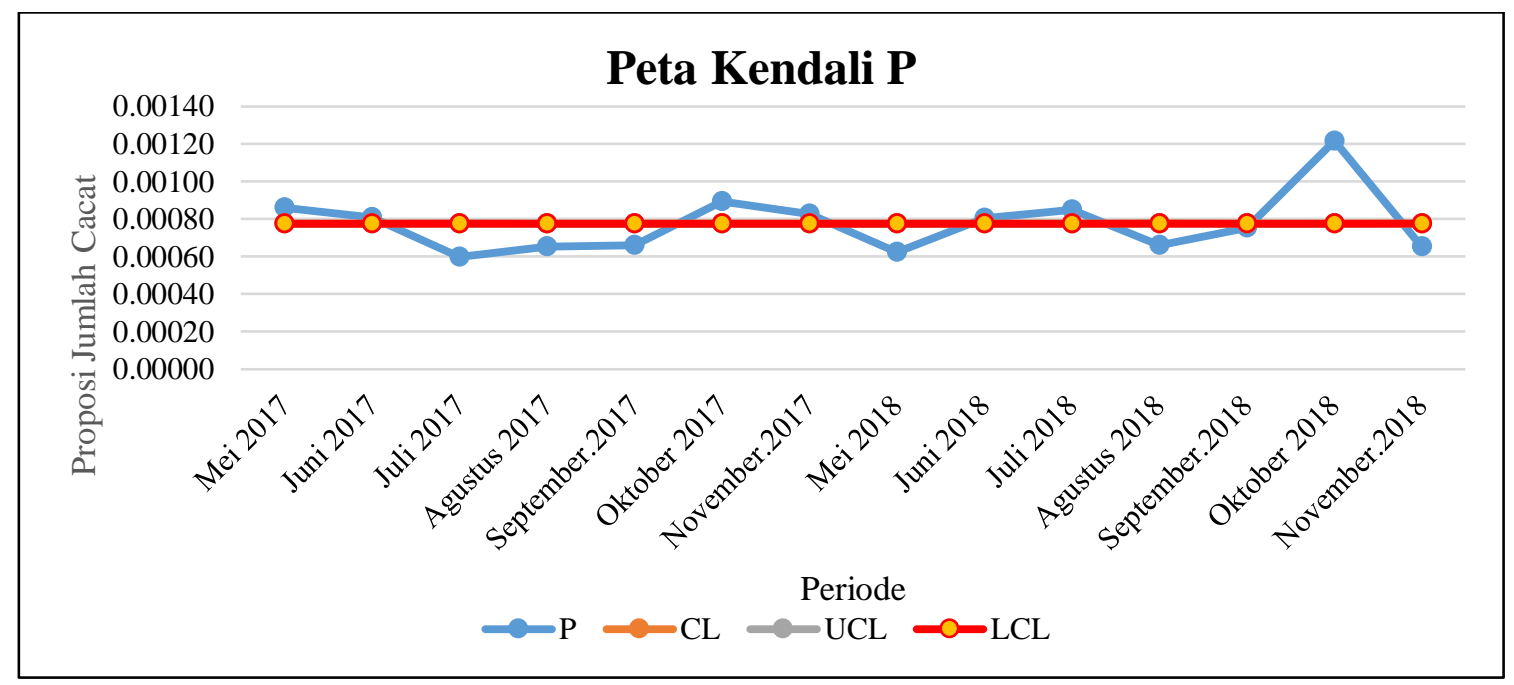

Gambar 4. Peta Kendali P

7. Jika terdapat titik berada di luar batas UCL dan LCL artinya produk cacat yang dihasilkan periode tersebut berada di atas atau di bawah toleransi yang ditetapkan.

Berdasarkan Gambar 4. dapat dilihat bahwa nilai UCL dan LCL

proporsi jumlah produk cacat dari Bulai Mei 2017 sampai November 2017 dan Mei 2018 sampai November 2018 terdapat nilai yang berada di atas batas kendali atas (UCL), yaitu pada Tahun 2017 di bulan Mei, Juni, Oktober, November dan pas Tahun 2018 di bulan Juni, Juli, Oktober. Tingginya tingkat kecacatan pada bulanbulan tersebut menandakan adanya fakator-faktor yang mempengaruhinya. Faktor-faktor tersebut bisa disebabkan oleh Manusia, Mesin, Material, Metode dan Lingkungan kerja pada suatu perusahaan. Untuk itu perlu dilakukan analisis Sebab Akibat (fishbone diagram) untuk mengetahui sebab tingginya tingkat kecacatan suatu produk.

\section{Diagram Sebab Akibat}

Mencari faktor penyebab yang dominan dengan menggunakan diagram sebab akibat (cause and effect diagram). Diagram sebab akibat untuk jenis kerusakan terjepit mesin dapat dilihat pada Gambar 5. Diagram sebab akibat untuk jenis kerusakan jahitan lepas dapat 
dilihat pada Gambar 6. Diagram sebab akibat untuk jenis kerusakan karena conveyor dapat dilihat pada Gambar 7.

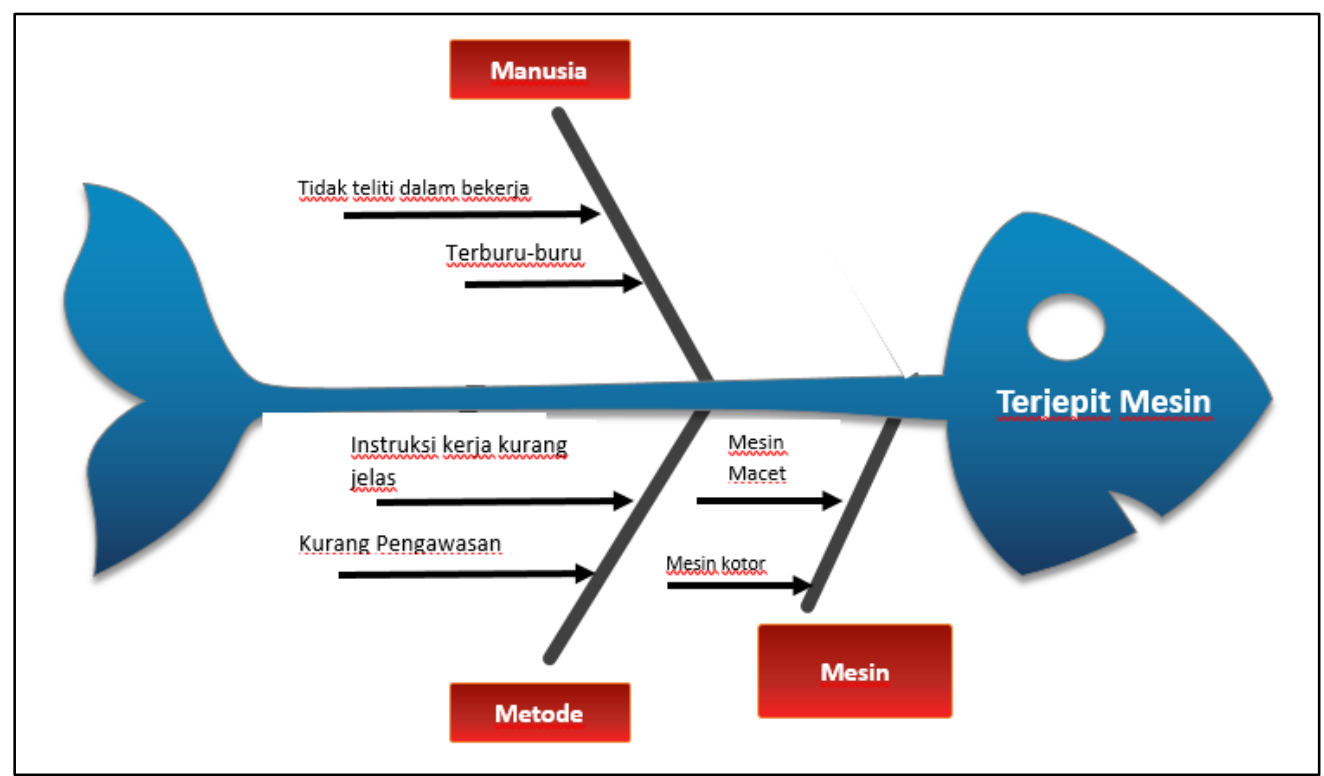

Gambar 5. Fishbone Diagram Kerusakan Terjepit Mesin

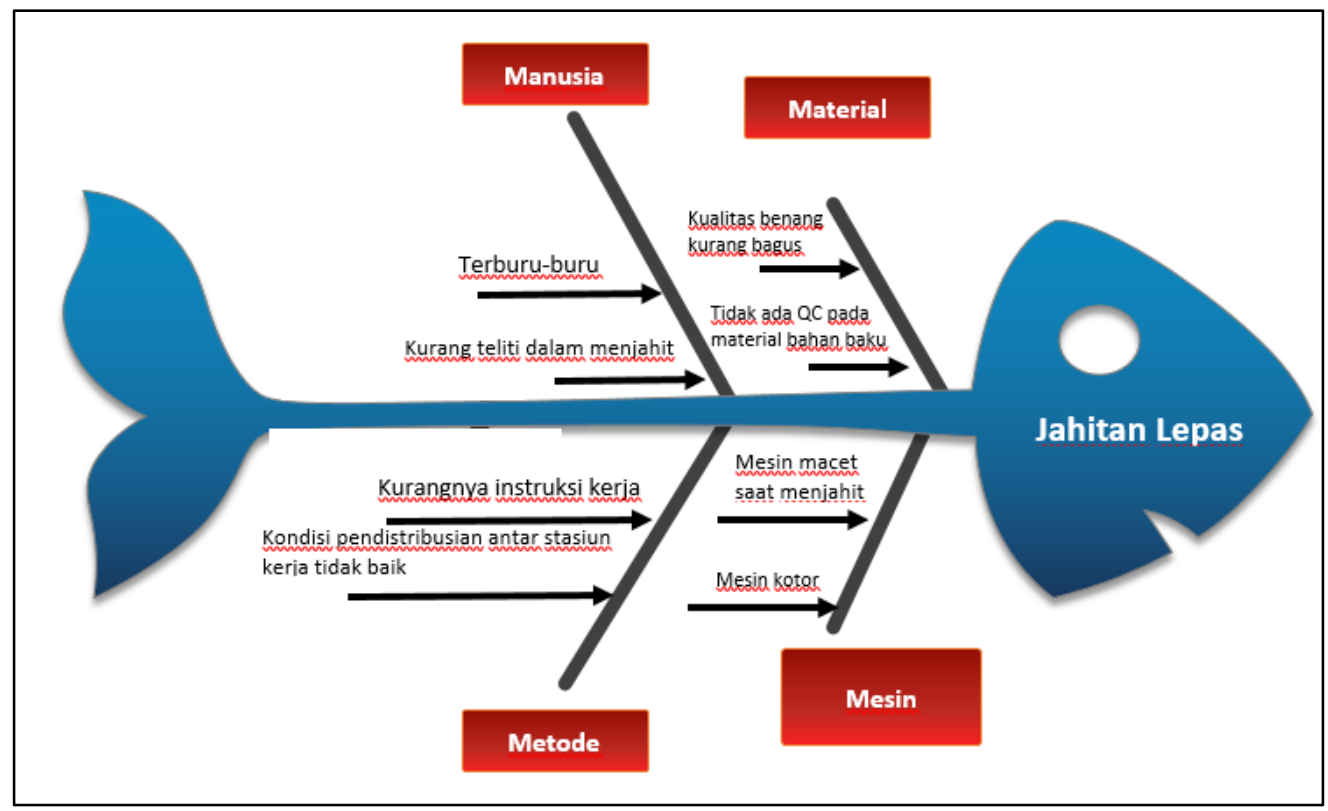

Gambar 6. Fishbone Diagram Kerusakan Jahitan Lepas 


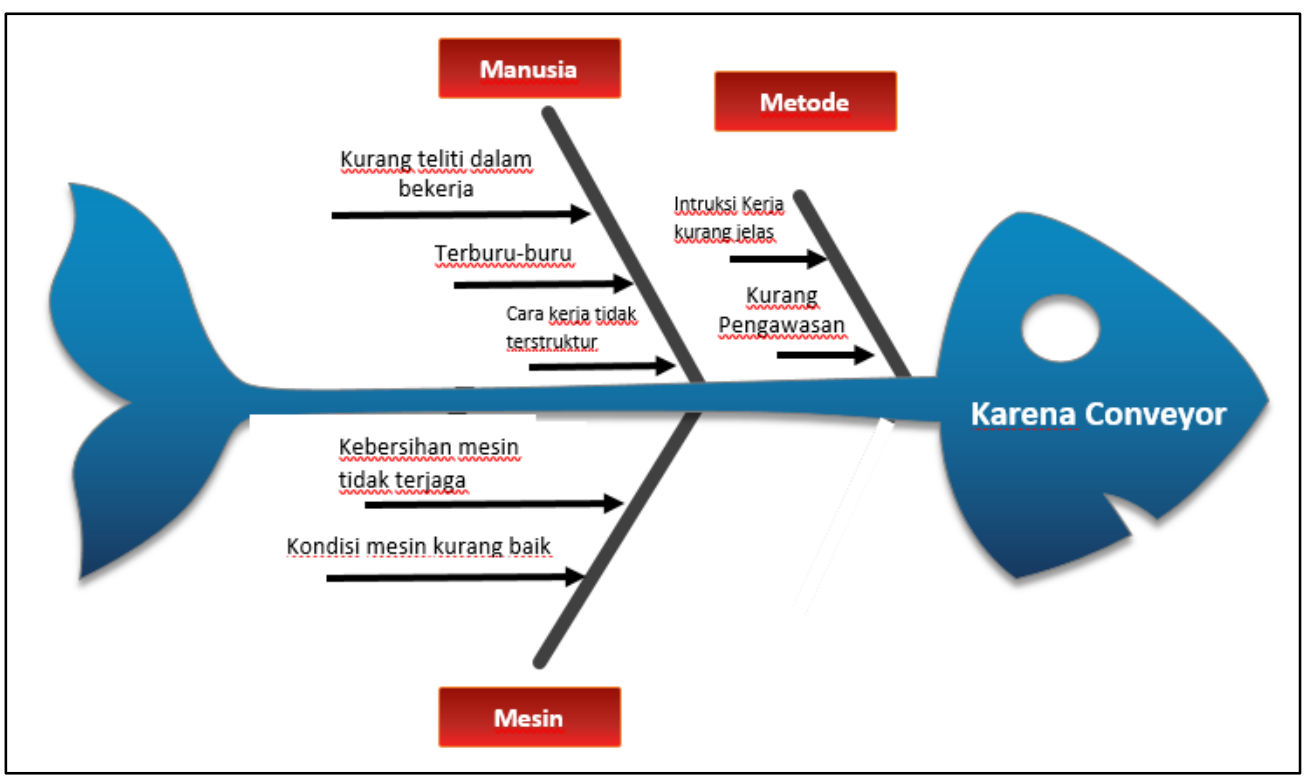

Gambar 7. Fishbone Diagram Kerusakan karena Conveyor

\section{Usulan Perbaikan}

Membuat rekomendasi usulan perbaikan kualitas berdasarkan perolehan hasil pengolahan data penyebab teradinya kerusakan produk, Usulan perbaikan yang diberikan untuk setiap jenis kerusakan dapat dilihat pada Tabel 2, Tabel 3, dan Tabel 4.

Tabel 2. Usulan Perbaikan Jenis Kerusakan Terjepit Mesin

\begin{tabular}{|c|c|c|}
\hline & Faktor Penyebab & Usulan Tindakan Perbaikan \\
\hline Manusia & $\begin{array}{l}\text { - } \quad \text { Tidak teliti dalam bekerja } \\
\text { - } \quad \text { Terburu-buru }\end{array}$ & $\begin{array}{ll}\checkmark & \text { Melakukan pengarahan yang lebih sering kepada para } \\
& \text { karyawan } \\
\checkmark & \text { Memberikan sanksi kepada pekerja yang ceroboh }\end{array}$ \\
\hline Mesin & $\begin{array}{l}\text { - } \quad \text { Mesin macet } \\
\text { - } \quad \text { Mesin kotor }\end{array}$ & $\begin{array}{l}\text { Melakukan perawatan secara berkala untuk mesin yang } \\
\text { digunakan } \\
\text { Mengarahkan karyawan untuk selalu merwat dan } \\
\text { membersihkan area kerjanya baik sebelum maupun } \\
\text { sesudah bekerja }\end{array}$ \\
\hline Metode & $\begin{array}{ll}\text { - } & \text { Intruksi kerja kurang jelas } \\
\text { - } & \text { Kurang pengawasan }\end{array}$ & $\begin{array}{l}\checkmark \quad \text { Membuat instruksi kerja yang jelas dapat ditempatkan } \\
\text { diseluruh area kerja } \\
\checkmark \quad \text { Melakukan pengawasan secara berkala terhadap kerja } \\
\text { karyawan }\end{array}$ \\
\hline
\end{tabular}

Tabel 3. Usulan Perbaikan Jenis Kerusakan Jahitan Lepas

\begin{tabular}{|c|c|c|}
\hline & Faktor Penyebab & Usulan Tindakan Perbaikan \\
\hline Manusia & - $\quad$ Terburu-buru & Memberikan sanksi kepada pekerja yang ceroboh \\
\hline & $\begin{array}{l}\text { Kurang teliti dalam } \\
\text { menjahit }\end{array}$ & $\checkmark \begin{array}{l}\text { Melakukan pengarahan yang lebih sering kepada para } \\
\text { karyawan }\end{array}$ \\
\hline Mesin & $\begin{array}{l}\text { - } \quad \text { Mesin macet saat menjahit } \\
\text { - Mesin kotor }\end{array}$ & $\begin{array}{l}\checkmark \quad \text { Melakukan perawatan secara berkala untuk mesin yang } \\
\text { digunakan } \\
\checkmark \quad \text { Mengarahkan karyawan untuk selalu merawat dan } \\
\text { membersihkan area kerjanya baik sebelum maupun } \\
\text { sesudah bekerja }\end{array}$ \\
\hline Metode & $\begin{array}{l}\text { - } \quad \text { Kurangnya instruksi kerja } \\
\text { - } \quad \text { Kondisi pendistribusian } \\
\text { antar stasiun kerja tidak baik }\end{array}$ & $\begin{array}{l}\checkmark \quad \text { Membuat instruksi kerja yang jelas dapat ditempatkan di } \\
\text { seluruh area kerja } \\
\checkmark \quad \begin{array}{l}\text { Melakukan pengawasan dan pengecekan pada proses } \\
\text { pendistribusian antar stasiun kerja }\end{array}\end{array}$ \\
\hline Material & $\begin{array}{l}\text { Kualitas benang kurang } \\
\text { bagus } \\
\text { - Tidak ada QC pada material } \\
\text { bahan baku }\end{array}$ & $\begin{array}{ll}\checkmark & \text { Memilih/membeli benang yang berkualitas baik } \\
\checkmark & \text { Melakukan QC setiap penerimaan bahan baku }\end{array}$ \\
\hline
\end{tabular}


Tabel 4. Usulan Perbaikan Jenis Keusakan Karena Conveyor

\begin{tabular}{|c|c|c|}
\hline & Faktor Penyebab & Usulan Tindakan Perbaikan \\
\hline Manusia & $\begin{array}{ll}\text { - } & \text { Kurang teliti dalam bekerja } \\
\text { - } & \text { Terburu-buru } \\
\text { - } & \text { Cara kerja tidak terstruktur }\end{array}$ & $\begin{array}{ll}\checkmark & \text { Melakukan pengarahan yang lebih sering kepada para } \\
& \text { karyawan } \\
\checkmark & \text { Memberikan sanksi kepada pekerja yang ceroboh } \\
\checkmark & \text { Memberikan instruksi kerja yang jelas pada setiap area kerja }\end{array}$ \\
\hline Mesin & $\begin{array}{l}\text { - } \quad \text { Kondisi mesin kurang baik } \\
\text { - Kebersihan mesin tidak } \\
\text { terjaga }\end{array}$ & $\begin{array}{l}\checkmark \text { Melakukan perawatan secara berkala untuk mesin yang } \\
\text { digunakan } \\
\checkmark \\
\text { Mengarahkan karyawan untuk selalu merawat dan } \\
\text { membersihkan area kerjanya baik sebelum maupun sesudah } \\
\text { bekerja }\end{array}$ \\
\hline Metode & $\begin{array}{l}\text { - } \quad \text { Instruksi kerja kurang jelas } \\
\text { - } \quad \text { Kurang pengawasan }\end{array}$ & $\begin{array}{l}\checkmark \quad \text { Membuat instruksi kerja yang jelas dapat ditempatkan di } \\
\text { seluruh area kerja } \\
\checkmark \\
\text { Melakukan pengawasan dan pengecekaan secara berkala } \\
\text { pada setiap area kerja }\end{array}$ \\
\hline
\end{tabular}

\section{KESIMPULAN}

Kesimpulan dari penelitian ini adalah :

1. Terdapat tiga jenis kerusakan pada proses pengemasan gula yaitu jenis cacat karena terjepit mesin, jenis cacat karena jahitan lepas dan jenis cacat karena conveyor.

2. Pengendalian kualitas yang telah dilakukan menggunakan Statistical Process Control (SPC) dengan tujuh alat bantu (seven tools) yaitu Check Sheet, Histogram, Diagram Pareto, Peta Kendali, dan Diagram Sebab Akibat (Fishbone).

3. Jenis kerusakan yang paling besar yaitu jenis cacat karena conveyor dengan nilai sebesar $38,17 \%$, ini dapat disebabkan oleh kesalahan manusia dan faktor lainnya sepeti kondisi mesin, kebersihan mesin serta proses pengawasan.

4. Usulan perbaikan yang direkomendasikan untuk perusahaan adalah memberikan pelatihan kepada karyawan, membuat instruksi kerja yang jelas, melakukan perawatan secara berkala untuk mesin yang digunakan, melakukan pengawasan pada seluruh area kerja, dan melakukan quality control untuk setiap penerimaan bahan baku.

\section{DAFTAR PUSTAKA}

[1] Montgomery, Duoglas C. 2013. Introduction to Statistical Quality Control (7 $7^{\text {th }}$ edition). USA: John Wiley \& Son, Inc

[2] Chandra, Jeya M. 2001. Statistical Quality Control. USA: CRC Press, LLC

[3] Khamaludin., Respati, Anang Pandan. "Implementasi Metode QCC untuk Menurunkan Jumlah Sisa Sampel Pengujian Compound". Jurnal Optimasi Sistem Industri - Vol. 18. No. 2. 2019. pp 176-185

[4] Clute, Mark. 2009. Food Industry Quality Control Systems. USA: CRC Press, LLC
[5] Hubbard, Merton R. 2003. Statistical Quality Control for the Food Industry (3 ${ }^{\text {rd }}$ edition). New York: Plenum Publishers

[6] Andespa, Ira. “Analisis Pengendalian Mutu Dengan Menggunakan Statistical Quality Control (SQC) Pada PT. Pratama Abadi Industri (JX) Sukabumi”. EJurnal Ekonomi dan Bisnis Universitas Udayana. Vol. 9 No. 2. 2019. pp 129-160. 